IJOTL TL, Vol. 4, No. 2, May 2019

p ISSN: 2502 2326; e ISSN: 2502 8278

Https://soloclcs.org; Email: ijolt1@gmail.com

Center of Language and Cultural Studies, Surakarta, Indonesia

Suhirman, Lalu \& Rinantanti, Yulini. 2019. Competence of EFL Junior High School Teachers

In Implementing Classroom Assessment in Merauke District, Papua.

IJOTL TL (2019), 4(2): 65 80. DOI: 10.30957/ijotl- fl.v4i2.261

\title{
Competence of EFL Junior High School Teachers \\ in Implementing Classroom Assessment in Merauke Distict, Papua
}

\author{
Lalu Suhirman \& Yulini Rinantanti \\ Universitas Cenderawasih, Papua-Indonesia \\ Email: lalusuhermanmpd@gmail.com \& yrinantanti@gmail.com
}

\begin{abstract}
The goal of this study was to explore the classroom assessment comprehension of EFL-JHS (Junior High School) teachers in Merauke District. A descriptive evaluative research design was used to describe objectively and evaluate several variables related to the competence of EFL teachers in implementing classroombased assessment (CBA) in English subject. This research was carried out in Merauke district. The sample used in this study was all the number of populations that we term to the total sampling or purposive sampling, namely 56 respondents. Questionnaires were distributed to 56 respondents, but in the allotted time only 25 returned the questionnaires. Of the 25 questionnaires were returned to the researchers, there were 18 questionnaires stated as feasible and complete to be analyzed while 7 questionnaires were declared incomplete. There were three instruments used to collect data: questionnaire, interview, and focus group discussion (FGD). The results showed that respondents' understanding of the principles and characteristics of CBA was that $9(50 \%)$ respondents claimed to understand and $9(50 \%)$ said they did not understand. They did not understand CBA generally lived and taught in remote areas and stated that they did not have sufficient access to conduct training or curriculum workshops or other professional development.
\end{abstract}

Key-words: classroom-based assessment, authentic assessment, instrument, professional

\section{INTRODUCTION}

Assessment is an important part of the learning process. Assessment is carried out to see the extent to which the learning process that has taken to reach the stated goals. Assessment should be able to see and display students' profiles as a whole which includes three domains in education, cognitive, affective, and psychomotor (Bloom, 1963). But in reality, the assessment process of learning is still dominant in the positive domain, so that the achievement of competencies that touch affective and psychomotor is still very lacking and has not been developed by many teachers.

One component in the Competency Based Curriculum (CBC) or Education Unit Level Curriculum (EULC) recommends a classroom based evaluation model that can assess the learning process in the classroom as a whole and comprehensively. Classbased assessment that encourages the use of judgments that can include not only the cognitive domain but also the affective and psychomotor domains. This assessment 
IJOTL TL, Vol. 4, No. 2, May 2019

p ISSN: 2502 2326; e ISSN: 2502 8278

Https://soloclcs.org; Email: ijolt1@gmail.com

Center of Language and Cultural Studies, Surakarta, Indonesia

Suhirman, Lalu \& Rinantanti, Yulini. 2019. Competence of EFL Junior High School Teachers

In Implementing Classroom Assessment in Merauke District, Papua.

IJOTL TL (2019), 4(2): 65 80. DOI: 10.30957/ijotl- fl.v4i2.261

model is expected to be applied in the classroom (not only in English language lessons but for all subjects) so that it can further strengthen and support the implementation of active, innovative, creative, effective, and fun learning in schools and at the same time it encourages the mastery of competencies such as expected in the education national standard (SNP).

Classroom assessment is a teacher's competence and activities related to decision making about the achievement of students' competencies or learning outcomes that follow a particular learning process. For this reason, data is needed as a basis for decision making. The decision in question relates to whether or not the student has succeeded in achieving a competency. The assessment process requires the collection of assessment evidence that is carried out intentionally, systematically, and continuously and is used to assess students' competencies. The process of gathering evidence includes: (1) providing opportunities for students to demonstrate their competence; (2) collect and record demonstrations of student competencies, and; (3) use evidence to make a thorough assessment of the demonstration or residual performance in the competency in question.

Competency-based education paradigm includes curriculum, pedagogy, and assessment that emphasizes certain standards of residual learning outcomes. The curriculum contains teaching materials given to students through the learning process. The learning process is carried out using pedagogic which includes strategies, methods, approaches, and learning theories, while the success rates achieved by students can be seen in the assessment results which include assessment, assignments and observations.

One assessment model recommended in EULC is classroom-based assessment that can measure all areas of student competence, namely; cognitive, affective, and psychomotor and carried out in various ways. Therefore, researchers are very interested in reviewing the mastery of Merauke district of Junior High School (JHS) English teachers' assessment competency as one of the pedagogic sub-competencies that includes the definition of assessment standards, the development of learning assessment instruments, and the principles of educational assessment in accordance with the regulation of Ministerial of National Education (MoNE) Number 20 in year 2007.

Based on the discussion above, the purpose of this study was to identify the classroom assessment comprehension of EFL-JHS teachers in Merauke District. Specific research questions to be addressed were as follows:

1. Do EFL-JHS teachers of Merauke district understand the principles of classroombased assessment?

2. Are EFL-JHS teachers of Merauke district able to determine the techniques and forms of classroom-based assessment?

3. How is the ability of EFL-JHS teachers of Merauke district to develop assessment instruments by using tests and non-tests in classroom assessments?

4. How do EFL-JHS teachers of Merauke district in implementing classroom assessment in the instructional process?

From the description of the research problem formulation above, the purpose of this research is to: 
IJOTL TL, Vol. 4, No. 2, May 2019

p ISSN: 2502 2326; e ISSN: 2502 8278

Https://soloclcs.org; Email: ijolt1@gmail.com

Center of Language and Cultural Studies, Surakarta, Indonesia

Suhirman, Lalu \& Rinantanti, Yulini. 2019. Competence of EFL Junior High School Teachers

In Implementing Classroom Assessment in Merauke District, Papua.

IJOTL TL (2019), 4(2): 65 80. DOI: 10.30957/ijotl-tl.v4i2.261

1. investigate EFL-JHS teachers' understanding towards the principles of classroombased assessment;

2. identify the competence of EFL-JHS teachers in determining the techniques, forms and characteristics of classroom-based assessment;

3. describe the ability of EFL JHS teachers in developing assessment instruments by using tests and non-tests on classroom - based assessments;

4. explore how EFL-JHS teachers implement classroom-based assessment in the instructional process.

\section{LITERATURE REVIEW}

\subsection{Evaluation and Assessment}

In a simple term, an assessment can be interpreted as a measurement and nonmeasurement process to obtain data on student characteristics with certain rules. In the implementation of learning assessment, the teacher will be faced with 3 (three) terms that are often confused with their understanding, or even often used together, namely the terms of measurement, assessment and test. To be able to further understand the implementation of the assessment of learning as a whole, it is necessary to understand the differences in understanding and relationships between the three terms, and how they are used in learning assessment.

In simple terms, measurement can be interpreted as an activity or effort made to give numbers to a phenomenon or event, or an object, so the measurement results will always be in the form of numbers. The tools for making these measurements can be standard measuring instruments such as meters, kilograms, liters, etc., including subjective measures that are relative, such as fathom, inch, "soon", and others. In the learning process the teacher also measures the learning process and results, the results of which are figures that reflect the achievements and processes and outcomes of the learning.

Figures 50, 75, or 175 obtained from the results of the measurement process and learning outcomes are quantitative and cannot provide any meaning, because they have not stated the level of quality of what is measured. The number of results of this measurement is usually called the raw score. The new measurement results have meaning when compared to certain criteria or standards.

Brown (2001) suggests that 'assessment is defined what students regard as important, how they spend their time and how they come to see themselves as individuals'. Gibbs and Simpson (2004) suggest that 'assessment is seen to exert a profound influence on student learning: on what students focus their attention on, on how much they study, on their quality of engagement with learning tasks, and, through feedback, on their understanding and future learning'.

\subsection{Classroom Assessment}

Classroom Assessment helps individual college teachers obtain useful feedback on what, how much, and how well their students are learning. Faculty can then use this information to refocus their teaching to help students make their learning more efficient and more effective (Angelo \& Croos, 1998:4). Through practice in Classroom 
IJOTL TL, Vol. 4, No. 2, May 2019

p ISSN: 2502 2326; e ISSN: 2502 8278

Https://soloclcs.org; Email: ijolt1@gmail.com

Center of Language and Cultural Studies, Surakarta, Indonesia

Suhirman, Lalu \& Rinantanti, Yulini. 2019. Competence of EFL Junior High School Teachers

In Implementing Classroom Assessment in Merauke District, Papua.

IJOTL TL (2019), 4(2): 65 80. DOI: 10.30957/ijotl-tl.v4i2.261

Assessment, aptitude becomes better able to understand and promote learning, and increase their ability to help the students themselves become more effective, selfassessing, self-directed learners. Simply put, the central purpose of Classroom Assessment is to empower both teachers and their students to improve the quality of learning in the classroom (Angelo \& Croos, 1998).

Classroom Assessments are created, administered, and analyzed by teachers themselves on questions of teaching and learning that are important to them, the likelihood that instructors will apply the results of the assessment to their own teaching is greatly enhanced (Anderson, 2003; Mendikbud, 2013 ). Classroom Assessment can be a planning and an assignment (Shermis \& Di Vesta, 2011). Shermis further explains that $\mathrm{CA}$ is the planned collection of information about the outcomes of teaching on student learning. The assignment of grades serves to inform stakeholders about the educational progress of students and achievement of curricular goals within the context of student readiness characteristics. Feedback from assessment helps teachers and students to demonstrate their decisions (Shemis \& Di Vesta, 2011; Anderson, 2003) regarding: a) effectiveness of instruction; b) identification of the need for changes in instructional methods; c) adaptation to or accommodation of individual differences; d) monitoring teaching in terms of student progress; e) setting of appropriate curricular goals in terms of content standards; and f) remedial strategies needed to fix ineffective instructional methods.

Angelo, provides insights into effective classroom assessment; however, four generalizations are particularly relevant in administering the CA: (1) Feedback from classroom assessments should give students a clear picture of their progress on learning goals and how they might improve; (2) Feedback on classroom assessments should encourage students to improve; (3) Classroom assessment should be formative in nature; and (4) Formative classroom assessments should be frequent (Angelo \& Croos, 1998). On the other side, McMillan (2013) states three components of a valid classroom assessment system: "a model of student cognition and learning in the domain, a set of beliefs about the kinds of observations that will provide evidence of students' competencies, and an interpretation process for making sense of the evidence"

\subsection{Authentic Assessment}

Authentic assessment is a significant assessment of student learning outcomes for the domain of attitudes, skills, and knowledge. Authentic terms are original, natural, valid, or reliable synonyms. Conceptually, authentic assessment is more important than even a standardized multiple choice test (Mendikbud, 2013). Authentic assessment is able to describe an increase in student learning outcomes, both in order to observe, reason, try, build networks, and others. Authentic assessment tends to focus on complex or contextual tasks, allowing students to demonstrate their competence in a more authentic setting (Dung \& Ha Ngunyen, 2019; Meyer, 1992).

Authentic assessment calls for authentic performances, which include real-life decisions, such as the behaviors of aestheticians, architects, art historians and critics, artists such as folk artists, people working in all forms who confront art in their daily lives, and people whose a vocational activities relate to art. Authentic learning in art 
IJOTL TL, Vol. 4, No. 2, May 2019

p ISSN: 2502 2326; e ISSN: 2502 8278

Https://soloclcs.org; Email: ijolt1@gmail.com

Center of Language and Cultural Studies, Surakarta, Indonesia

Suhirman, Lalu \& Rinantanti, Yulini. 2019. Competence of EFL Junior High School Teachers

In Implementing Classroom Assessment in Merauke District, Papua.

IJOTL TL (2019), 4(2): 65 80. DOI: 10.30957/ijotl-tl.v4i2.261

implies purposeful, meaningful application of relevant information, as opposed to the acquiring of factual knowledge for its own sake. It also inspires changes in curricular practices in the assessment process (Dorn, Madeja, \& Sabol, 2004).

Authentic assessment is often described as an assessment of the development of students because it focuses on their developing ability to learn how to learn about the subject. The Authentic assessment must be able to describe the attitudes, skills, and knowledge of what students have or have not, how they apply their knowledge, in terms of what they have or have not been able to implement learning acquisition, and so on (Mendikbud, 2013).On that basis, the teacher can identify what material is feasible to continue and for what material remedial activities should be carried out.

\subsection{Alternative Assessment}

Authentic assessment can be defined as a special kind of performance assessment conducted in an authentic context as part of regular classroom learning rather than as contrived, intrusive assessment tasks (Gipps, 1994). Alternative assessment, as characterized by Aschbacher (1991) requires problem solving and higher level thinking, involves tasks that are worthwhile as instructional activities, uses real-world contexts or simulations, focuses on processes as well as products. Yarden, Madeja, \& Phillips (2015) suggested that authentic activities are the "ordinary practices of the culture" and can be as alternative assessment. Ha Nguyen (2019) implicitly states two kinds of authentic alternative assessment, such as performance and portfolio, while (Mendikbud, 2013) adds two more alternative assessment, project and product.

Performance-based assessments require students to use high level thinking to perform, create, or produce something with transferable real-world application. Research has also shown that they provide useful information about student performance to students, parents, teachers, principals, and policymakers (Matthews, 1995; Koretz et al., 1996). Research on thinking and learning processes also shows that performance-based assessments propel education systems in a direction that corresponds with how individuals actually learn (Herman, 1992). The term performance-based assessment is often used when referring to a broad spectrum of assessment types. Among those are alternative assessments and authentic assessments (Dung \& Ha Ngunyen, 2019; Meyer, O’Malley \& Valdez, 1996).

O’Malley \& Valdez Pierce (1996) state that "an assessment portfolio is the systematic collection and evaluation of student work measured against predetermined scoring criteria, such as scoring guides, rubrics, checklists, or rating scales". Portfolios can provide a continuous picture of student progress, rather than a snapshot of student achievement that single- occasion tests provide. Depending on school or district requirements, portfolios can include performance-based assessments, such as writing samples that illustrate different genres; solutions to math problems that show problemsolving ability; lab reports demonstrating an understanding of a scientific approach; or social studies research reports demonstrating the ability to use multiple sources.

Portfolio assessment is the procedure used to plan, collect and analyze the multiple sources of data maintained in the portfolio (Mendikbud, 2013: Yarden, Norris $\&$ Pillips, 2015). The process includes student participation in the selection of work, in 
IJOTL TL, Vol. 4, No. 2, May 2019

p ISSN: 2502 2326; e ISSN: 2502 8278

Https://soloclcs.org; Email: ijolt1@gmail.com

Center of Language and Cultural Studies, Surakarta, Indonesia

Suhirman, Lalu \& Rinantanti, Yulini. 2019. Competence of EFL Junior High School Teachers

In Implementing Classroom Assessment in Merauke District, Papua.

IJOTL TL (2019), 4(2): 65 80. DOI: 10.30957/ijotl-tl.v4i2.261

criteria, goal setting and through self-assessment. Students and teacher collaborate in assessing and evaluating students learning from evidence in portfolio collection (Marano, 2006), then use the information to make plan and set goals for further learning. That means, the assessment is not unilateral. Portfolio assessment contain guidelines for content, criteria for evaluating process and product as well as evidence of students' reflection (Macleod \& Erlandson, 2012).

\section{METHODS}

In this study, a descriptive evaluative research design was used, because researchers wanted to describe objectively and evaluate several variables related to the competence of EFL teachers in implementing classroom-based assessments in English subject. This research was carried out in Merauke Regency for junior high school English teachers, public and private schools which covering Merauke Regency.

The population of this study was all English teachers who taught in Merauke Regency. Information obtained from the head of the MGMP (Deliberation of English subject teachers), there were 56 English teachers. The sample used in this study was all the number of populations that we term to the total sampling or purposive sampling, namely 56 English teachers. Questionnaires were distributed to 56 English teachers, but in the allotted time only 25 returned the questionnaires. Of the 25 questionnaires that were returned to the researchers, there were 18 questionnaires stated as feasible and complete to be analyzed while 7 questionnaires were declared incomplete.

The instruments used to collect data in this study were questionnaires, interviews, and focus group discussions (FGD). The questionnaire used was a questionnaire about classroom-based assessments made by the Standard National Education Board (BNSP). Data collected in this study include primary data and secondary data. Primary data (main data) was collected directly from respondents in the field. The primary data collection technique was used in three ways, namely through questionnaire, interview, and FGD. While for secondary data, it was obtained through documentation studies in the form of relevant documents, such as curriculum documents, lesson plans, and books or references related to research problems.

Data obtained through questionnaire instruments were analyzed using practical applied statistical techniques by calculating percentages, while data obtained through interviews and FGD were analyzed qualitatively. To interpret respondents' responses simply it is looking at the percentage of respondents' answers. The value of each aspect, then it is classified according to certain categories or criteria so as to provide meaning and interpretation of each item or aspect. To interpret the results of this study criteria or benchmarks are used as follows: (a) $81-100$ = very competent, very good, very adequate; (b) 71-80 = competency is good, adequate, complete; (c) 61-70 = sufficient competence, quite adequate, quite complete; (d) 51-60 = lack of competence, inadequate, incomplete; and (e) 10-50 = very lack of competence, very low, very inadequate. 
IJOTL TL, Vol. 4, No. 2, May 2019

p ISSN: 2502 2326; e ISSN: 2502 8278

Https://soloclcs.org; Email: ijolt1@gmail.com

Center of Language and Cultural Studies, Surakarta, Indonesia

Suhirman, Lalu \& Rinantanti, Yulini. 2019. Competence of EFL Junior High School Teachers

In Implementing Classroom Assessment in Merauke District, Papua.

IJOTL TL (2019), 4(2): 65 80. DOI: 10.30957/ijotl -1.v4i2.261

\section{FINDING AND DISCUSSION}

\section{1 Teacher's understanding of classroom-based assessment}

In the Education Unit Level Curriculum (EULC) for all levels or educational units in Indonesia there is a paradigm shift in implementing EULC. In the old paradigm, the teacher as the center and the main learning source but in the new paradigm that in the learning process students become the center and learning resources and the teacher is positioned as a facilitator that serves to provide the best service for students.

To see the quality of student learning outcomes, assessment is not merely seen from the results of student memorization but can be conducted in various ways. One of the assessment models recommended in Competency-Based Curriculum (CBC) is a classroom-based assessment (CBA). This CBA must be applied by all teachers field of study and classroom teachers as well as for all subjects. CBA is an assessment model that covers all the domains recommended by Bloom that must be mastered and owned by students, namely: cognitive, affective, and psychomotor. CBA directs the assessment of learning outcomes to be carried out in various ways and various forms or types such as portfolio, performance, process, project and pen and paper, where the tests given must be authentic. That is, what is tested or tested on students is really in accordance with what has been taught and learned by students (Puskur, 2009; Ministry of Education and Culture, 2013; Jalal, 2009)

Answering the number one of research problem formulation that focused on the knowledge of EFL-JHS teachers in Merauke district who were respondents in this study about class-based assessment (PBK), from table 1 shows that in table 1 questionnaire number 1 from $\mathrm{N}=18$ shows that 6 ( $33.33 \%)$ respondents stated that they did not understand and did not know what CBA was. Then $1(5.55 \%)$ respondent respectively admitted that they understood PBK strongly, $6(33.33 \%)$ teachers understood, and $5(27.77 \%)$ stated that they understood enough (see table 1number 1).

If we observe the data answered by the respondents about their understanding of CBA, it appears that around $66.66 \%$ have understood CBA from the level of understanding enough to be very understanding. However, it was very unfortunate that there were still $33.33 \%$ of respondents who did not know what CBC is. The lack of understanding of the 6 respondents was reasonable because they claimed (in the interview) that they had never attended CBC socialization or training. Because indeed, this CBA was a mandate or bill in the CBC. Assessment of student learning outcomes is no longer solely from the results of memorization of students (Marzano, 2016), or just assessing the cognitive domain but the assessment of student learning outcomes must be using various ways and assessing the three domains of learning namely cognitive, affective, and psychomotor (Dorn, Mardeja \& Sabol, 2004).

Regarding the focus focused on the CBA, there were only $33.33 \%$ of respondents who stated that they understood correctly the main point of CBA, namely achievement of indicators, and the remaining $66.66 \%$ of respondents said they did not know. Whereas related to the elements assessed in the CBA, there were $88.88 \%$ of respondents correctly answering the elements assessed in CBA, namely cognitive, affective, and 
IJOTL TL, Vol. 4, No. 2, May 2019

p ISSN: 2502 2326; e ISSN: 2502 8278

Https://soloclcs.org; Email: ijolt1@gmail.com

Center of Language and Cultural Studies, Surakarta, Indonesia

Suhirman, Lalu \& Rinantanti, Yulini. 2019. Competence of EFL Junior High School Teachers

In Implementing Classroom Assessment in Merauke District, Papua.

IJOTL TL (2019), 4(2): 65 80. DOI: 10.30957/ijotl- fl.v4i2.261

psychomotor, the remaining $2(11.11 \%)$ respondents mentioned inappropriate (see table 1 number 2 and 3 ).

If we look carefully at the respondents' understanding of the main point or focus assessed in the CBA, it appears that there were still many respondents who did not understand this because they were still accustomed to evaluating with the old model of assessing some material that has been taught, even though the CBA model in the education unit level curriculum (EULC) is simpler, which focuses on achieving indicators. According to respondents when conducting FGD, most respondents stated that in the learning process activities they were always using textbooks, and related to learning sequences, they felt match with the sequence of contents or topics in textbooks.

Data on the uses, functions, objectives, and principles of CBA indicate that 12 $(66.66 \%)$ respondents stated the usefulness of CBA correctly, and the remaining $44.44 \%$ stated varied. Then there are $9(50 \%)$ respondents stated that the CBA function was for remedial for students who have not completed learning, $2(11.11 \%)$ respondents stated for reinforcement for students who have completed learning well, and $6(33.33 \%)$ respondents stated that teachers could know student learning outcomes (see table 1 numbers 5 and 6). Whereas things related to the objectives of the CBA, almost all respondents $(88.88 \%)$ stated that they were well-versed, understood that until they fully understood the purpose of the CBA, only $1(5.55 \%)$ of respondents said she did not understand. For the CBA principle, $11(61.11 \%)$ respondents stated that they understood enough and to strongly understood the principles of CBA, while the remaining 7 $(38.88 \%)$ stated they did not know or did not know at all (see table 1 numbers $7,8,9)$.

Looking at the respondents' understanding of the functions, objectives, and principles of administering CBA, it appears that most of the respondents were in a position of understanding well or strongly understand. This can mean that the English teachers who are as respondents in this study have been able to reflect on teaching experience and understand the uses, functions, goals, and principles in carrying out student learning outcomes assessments. In fact, there is almost no difference between the use, function, purpose, and principle of assessment with the old model with CBA. Although there is something different from the usual or old assessment with CBA, respondents did not view it as a difference but were seen as an addition to the aspect.

Data concerning respondents' understanding of forms in CBA, it shows that there were $8(44.44 \%)$ of respondents stated that they understood enough to understand, but more respondents, around $10(55.55 \%)$ claimed that they did not understand (see table 2 questionnaire number 19). CBA also uses an actual valuation approach or authentic judgment. Respondents' understanding of the nature of authentic assessment showed that $7(38.88 \%)$ respondents did not understand the authentic nature of the assessment well, whereas as many as $11(61.11 \%)$ respondents stated that they understood it very well. Furthermore, related to the characteristics of authentic assessments, only 3 $(16.66 \%)$ respondents claimed not to understand, on the contrary, there were 15 $(83.33 \%)$ in positions of sufficient understanding to strongly understand, (see table 3 questionnaires number 25 and 28).

Observing respondents' understanding of the form and nature of authentic assessment shows that most respondents already understood and some respondents who 
IJOTL TL, Vol. 4, No. 2, May 2019

p ISSN: 2502 2326; e ISSN: 2502 8278

Https://soloclcs.org; Email: ijolt1@gmail.com

Center of Language and Cultural Studies, Surakarta, Indonesia

Suhirman, Lalu \& Rinantanti, Yulini. 2019. Competence of EFL Junior High School Teachers

In Implementing Classroom Assessment in Merauke District, Papua.

IJOTL TL (2019), 4(2): 65 80. DOI: 10.30957/ijotl- fl.v4i2.261

did not understand were still affected by the old pattern of assessments that only used tests. While the respondent's understanding of the characteristics of authentic assessments was quite encouraging, namely $83.33 \%$ of respondents understood the characteristics of authentic assessment, the remaining $16.66 \%$ of respondents said that they did not understand. For respondents who did not understand yet, it was suspected that they had never participated in in-service training on KTSP and the assessment recommended in EULC. However, EFL-JHS teachers who as respondents in this study should still be able to create and innovate in teachers' forum (MGMP) activities or training that conducted in their respective schools (in house training).

Authentic assessment, which is one form of CBA, has at least 5 characteristics, namely: (a) involving real experience; (b) carried out during the learning process; (c) includes personal judgment; (d) used as feedback; and (e) continuous. This is important to be well understood by the teacher and can be applied directly in the learning process. Learning methods and sources wherever possible use contextual learning, namely learning that is in accordance with the closest environment and what is experienced by students. This contextual learning approach fits the characteristics of authentic assessment.

Data about the understanding of respondents in applying authentic assessment, there were $5(27.77 \%)$ respondents claimed not to understand, and the remaining 13 $(72.22 \%)$ respondents expressed their understanding well or they felt strongly understand. While the respondent's understanding of the portfolio assessment, there were $16(88.88 \%)$ of respondents in a position of understanding enough and they also stated strongly understand, strongly understand $2(11.11 \%)$ respondents stated that they did not understand, (see table 4, questionnaires number 37 and 88).

The respondent's understanding of the tryout or practice of authentic assessment shows that most respondents had tried to apply authentic assessment. Likewise, with portfolio assessment, there were $16(88.88 \%)$ respondents admitted understanding well and usually apply it in the form of homework then documented by the teacher so that each student's work was not scattered. The forms of assessment in up-to-date CBA must be responded to promptly by the teacher, especially the English teacher because the form and principles of assessment in CBA are very relevant to teaching English.

\section{Techniques and Forms of Class-Based Assessment}

CBA techniques and forms use several methods, including portfolio, project, product, performance, and pen and paper (test). Data on the forms of CBA indicate that $10(55.55 \%)$ respondents could mention correctly and completely, and the remaining 8 (44.44\%) mention one to two forms of assessment, (see table 2 number 18, 19, and 20). Based on the results of the FGD and interviews with respondents, they did not know the form of authentic assessment, they merely guessed what authentic assessment was.

From the data above, it can be explained that the majority of respondents already knew this form of CBA, but those who did not know because they had never participated in the socialization of the competency-based curriculum including the curriculum devices. Some of the respondents explained the obstacles faced in participating in training or workshops in the city because they living and teaching places 
IJOTL TL, Vol. 4, No. 2, May 2019

p ISSN: 2502 2326; e ISSN: 2502 8278

Https://soloclcs.org; Email: ijolt1@gmail.com

Center of Language and Cultural Studies, Surakarta, Indonesia

Suhirman, Lalu \& Rinantanti, Yulini. 2019. Competence of EFL Junior High School Teachers

In Implementing Classroom Assessment in Merauke District, Papua.

IJOTL TL (2019), 4(2): 65 80. DOI: 10.30957/ijotl-tl.v4i2.261

were very far and included in very remote areas. However, each teacher is required to have pedagogical competence which includes designing learning and the ability to assess student learning outcomes based on EULC demands (Kemendikbud, 20012). Because the teachers have to try to learn and find out how to assess learning outcomes in accordance with the demands of the curriculum.

\section{Characteristics and Principles of Class-Based Assessment}

Data related to CBA principles indicate that $5(27.77 \%)$ respondents claimed to use 5 principles of CBA, $3(16.66 \%)$ respondents used 6 principles of CBA, $5(27.77 \%)$ respondents assessed 7 principles of $\mathrm{CBA}$, and $5(27.77 \%)$ respondents use $>8$ principles of CBA. The CBA principle was related to competency-oriented assessment, in which $12(6.66 \%)$ respondents stated that the achievement of competency concerns the standard of competence and basic competency, while $5(27.77 \%)$ respondents stated that achievement was based on goals, and only $1(5,55 \%)$ of respondents stated that the achievement of learning was based on basic competencies only. Then the data on the principle of assessment in the classroom, $14(77.77 \%)$ of respondents stated that the assessment was carried out during the learning process in the classroom, $1(5.55 \%)$ of respondents stated that the assessment was done at any time, $2(11.11 \%)$ respondents admitted that assessment is done at the end of the learning process (see table 1 numbers 10, 11 and 12).

One of the principles used in CBA is the assessment of the achievement of competencies, namely the achievement of competency standards and basic competencies. Achieving competencies by students must cover two basic competencies (McMIllan, 2013). Achievement of competence by students must include two competencies, namely the standard of competence and basic competency, because standard competencies cover broad aspects and basic competencies are sub-sections (material / topic) of competency standards (Marzano, 2006; Iron, 2008; Mcmillan, 2013). In its implementation, basic competencies must be described in the form of indicators to find out more specific achievements. For example, in English lessons, four language skills, such as: listening, speaking, reading, and writing as standard competencies for all education units. For mastery of listening, it is described in the form of basic competencies, then for aspects of speaking skills, it should be noted what things must be mastered by students, as well as other language skills.

Data concerning CBA characteristics using authentic assessment and portfolio shows that $15(83.33 \%)$ respondents stated that they were quite understanding, understanding, and totally understanding of the characteristics of CBA, and the remaining $3(1.66 \%)$ respondents said that they did not understand. Whereas for the principles of authentic assessment, only $4(22.22 \%)$ respondents could state the principle of authentic assessment correctly and completely, while as many as 14 (77.77\%) respondents mentioned one principle from authentic assessment. On the other hand, for the principle of portfolio assessment, there were $6(33.33 \%)$ respondents stating using four portfolio principles, $5(27.77 \%)$ respondents claiming to use five portfolio principles, and as many as $7(38.88 \%)$ respondents using six principles portfolio assessment. 
IJOTL TL, Vol. 4, No. 2, May 2019

p ISSN: 2502 2326; e ISSN: 2502 8278

Https://soloclcs.org; Email: ijolt1@gmail.com

Center of Language and Cultural Studies, Surakarta, Indonesia

Suhirman, Lalu \& Rinantanti, Yulini. 2019. Competence of EFL Junior High School Teachers

In Implementing Classroom Assessment in Merauke District, Papua.

IJOTL TL (2019), 4(2): 65 80. DOI: 10.30957/ijotl-tl.v4i2.261

Exposure of data about the characteristics and principles of authentic assessments and portfolios can be illustrated that the assessment of learning outcomes is not on one aspect so that in a competency-based curriculum (CBC) democratic judgments must be applied (Iron, 2008; McMillan, 2013). This means that the principle of assessment must benefit students by assessing all aspects and behaviors and activities of students related to academics. Therefore the CBA principle with authentic assessment is expected to be used to detect errors that cause weaknesses in the learning process because those judged must be in accordance with what has been learned and experienced by students, in other words assessing something that should be assessed (Angelo \& Cross, 1998; Airasian\& Russell, 2007).

The principles of authentic assessment must be developed by English teachers as respondents, namely: keeping track, checking up, finding out, and summing up (Puskur, 2009). Further explained that authentic assessment refers to integrated assessment and learning, which must be able to reflect real-world problems ( O'Malley \& Valdez, 1996; Marzano, 2006), not the school world, using various methods and criteria as well as holistic (full competence reflects knowledge, skills, and attitudes). Authentic assessment can be carried out continuously, meaning monitoring the process, progress, and continuous improvement of results in the form of daily tests, midterm tests, semester tests, and repeated increases in class (Marzano, 2006; Yarden, Norris, \&Phillips, 2015).

\section{4 Implementation of Class-Based Assessment}

Data on the competence of English teachers related to CBA implementation shows that it was known that $3(16.66 \%)$ respondents stated that the assessment was carried out after the teaching and learning process, $2(11.11 \%)$ respondents stated that they carried out the assessment before the learning process, $7(38.88 \%)$ stated that conducting an integrated assessment, $6(33.33 \%)$ of respondents stated that they made an assessment before and after the learning process (table 1 questionnaire number 4 ).

CBA is directed at four things in implementing it, wherein the assessment process the class was responded to differently by respondents, there was $1(5.55 \%)$ respondent stated that she/he conducted four things in the assessment process, 1 (5.55\%) other respondent stated that she/he did three things in the assessment process, $2(11.11 \%)$ respondents did two things, and at most 14 respondents $(77.77 \%)$ stated that they did only one activity in the assessment process (see table 1 questionnaire number 7).

If we examine the ability of English teachers in conducting learning outcomes in the CBA, it is clear that the majority of English teachers in Merauke Regency who were respondents in this study did not understand or did not yet know the rules of assessment in CBA. Only $7(38.88 \%)$ respondents from 18 people claimed to carry out an integrated assessment in accordance with the demands of the national education curriculum and system. Then, there are $6(33.33 \%)$ respondents who stated that they did the assessment before and after the learning process, indeed this method of assessment is usually done before the competency-based curriculum is applied. However, the CBA principle includes a variety of ways to measure student learning outcomes (Angelo \& Cross, 1998), therefore CBA in addition to evaluating at the beginning and end of learning activities is also carried out with an integrated strategy of assessing all cognitive, 
IJOTL TL, Vol. 4, No. 2, May 2019

p ISSN: 2502 2326; e ISSN: 2502 8278

Https://soloclcs.org; Email: ijolt1@gmail.com

Center of Language and Cultural Studies, Surakarta, Indonesia

Suhirman, Lalu \& Rinantanti, Yulini. 2019. Competence of EFL Junior High School Teachers

In Implementing Classroom Assessment in Merauke District, Papua.

IJOTL TL (2019), 4(2): 65 80. DOI: 10.30957/ijotl-tl.v4i2.261

affective, and psychomotor aspects (skills) using test instruments or non-test (Iron, 2008; McMillan, 2013).

CBA is directed at 4 components in the assessment process, namely: a) tracing so that the learning process remains in accordance with the plan; b) check whether the weaknesses experienced by students in the learning process; c) search and find things that cause weaknesses and errors in the learning process, and; d) conclude whether the student has achieved the specified competency or not. These four things should be a guide for teachers in carrying out student learning outcomes assessments. But from the acknowledgment of respondents only $2(11.11 \%)$ of the 18 people conducted CBA assessments using three and four considerations.

Regarding authentic assessment, almost all respondents $16(88.88 \%)$ out of 18 respondents claimed to have carried out authentic assessments even though they were still trying to use various methods such as using portfolio document instruments, written test results, quizzes, observation notes, group assignments, discussions, questionnaires, interviews, and teacher-made tests (see table 3 number 36). While assessing the portfolio model, all respondents claimed to have done or implemented it even though they did not always use all the principles of portfolio assessment in the learning process. In English lessons, respondents explained in the FGD and interviews that the form of portfolio assessment applied was homework book and student work sheets which were documented in special envelopes for each student. This file or document is then taken into consideration to give students the final grade.

\section{CONCLUSION}

The Understanding of EFL-JHS teachers in Merauke District towards the principles of CBA, there were $9(50 \%)$ of the 18 respondents who claimed to understand the principles of CBA, while the other half admitted that they did not understand the CBA at all, especially the principles contained therein. Respondents who did not understand this CBA generally lived and taught in remote areas and very far from the city of Merauke. The time needed from their residence to the city of Merauke can reach eight hours. That's why the respondents to did not have sufficient access to conduct training or curriculum workshops or other professional development. All the teachers stated that they knew the characteristics of CBA, but in practice, they still used the old method of assessing student learning outcomes from memorization or from what they had been taught using test instruments. One form of non-test assessment carried out by teachers which was interpreted as an assessment of projects and portfolios was homework. The homework given by the teacher had no effect on determining the final grade of the students, and it was considered as exercises by the teacher.

The implications of this study can be useful for teachers and prospective teachers that CBA is important to know because assessment is part of teacher pedagogic competence in which the teacher must provide an assessment of the learning process and student learning outcomes. Teachers can also take advantage of the results of CBA to determine forms of activities such as remedial, enrichment and improvement in the practice of classroom learning. 


\section{REFERENCES}

Airasian, P. W. \& Russell, M. (2007). Classroom assessment: concepts and applications. New York; London, McGraw-Hill Higher Education.

Angelo, T. A., \& Cross, K.P. (1998).Classroom Assessment Techniques: a handbook for college - (2nd ed). San Francisco: Jossy Bass Inc.

Aschbacher, P.R (1991). Performance assessment: State activity, interest, and concerns. Applied Measurement in Education, 4 (4), 275-288.

Brown, G. (2001) Assessment: a guide for lecturers, York, LTSN Generic Centre.

Conley, D.T. (2005). College knowledge: What it really takes for students to succeed and what we can do to get them ready. San Francisco: Jossey-Bass.

Dorn, C. M., Madeja,S.S., \&Sabol, F.R. (2004). A Practical Guide for TeacherDirected Authentic Assessment in K-12 Visual Arts Education. Mahwah, New Jersey London: Lawrence Erlbaum Associates, Publishers.

Dung, Le, Q., \& Ha Ngunyen, T.D. (2019) Portfolio - An Alternative Form of Assessment in EFL Context: International Journal of Scientific and Research Publications, (9), 1, pg. $439-445$.

Fadel, C., Honey, M. \&Pasnik, S. (2007). Assessment in the age of innovation. Education Week. May 18, 2007. Accessed April 2, 20019. http://www.edweek.org/ew/articles/2007/05/23/38fadel.h26.html?print=1

Gipps, C.V. (1994). Beyond testing: Towards a theory of educational assessment. London: The Falmer Press.

Gitomer, D. H., \&Duschl, R. A. (1995). Moving towards a portfolio culture in science education. In S. Glynn \& R. Duit (Eds.), Learning science in the schools' Research reforming practice (pp. 299-326).

Gibbs, G. and Simpson, C. (2004) 'Conditions under which assessment supports students' learning', Learning and Teaching in Higher Education, Vol. 1, No. 1, pp. $3-31$.

Herman, J. L. (1992). A practical guide to alternative assessment. Alexandria, VA: Association for Supervision and Curriculum.

Irons, A. (2008) Enhancing Learning through Formative Assessment and Feedback, New York: Routledge 
IJOTL TL, Vol. 4, No. 2, May 2019

p ISSN: 2502 2326; e ISSN: 2502 8278

Https://soloclcs.org; Email: ijolt1@gmail.com

Center of Language and Cultural Studies, Surakarta, Indonesia

Suhirman, Lalu \& Rinantanti, Yulini. 2019. Competence of EFL Junior High School Teachers

In Implementing Classroom Assessment in Merauke District, Papua.

IJOTL TL (2019), 4(2): 65 80. DOI: 10.30957/ijotl tl.v4i2.261

Knight, P. (2001) Formative and Summative, Criterion and Norm-Referenced

Assessment, LTSN Generic Centre, Assessment Series No. 7.

Koretz, D., Mitchell, K., Barron, S., \& Keith, S. (1996). Final Report: Perceived Effects of the Maryland School Performance Assessment Program. Los Angeles: National Center for Research on Evaluation, Standards, and Student Testing.

Matthews, B. (1995). The implementation of performance assessment in Kentucky classrooms. Louisville, KY: University of Louisville.

Macleod, J. \&Erlandson, C. (2012). Saskatchewan Professional Development Unit. Retrieved from http://www.uvm.edu/jmorris/cresource.html. Date: 20/5/2016

Mendikbud. (2013). DukumenKurikulum 13. Jakarta: KementerianPendidikan Dan Kebudayaan.

Meyer, C.A. (1992). What's the difference between authentic and performance assessment? Educational Leadership, 49 (8), 39- 40.

MONE. 2003. National Educational System, Act of the Republic of Indonesia Number 20, Year 2003. Jakarta: MONE.

MONE. 2005. Law Number 14 Year 2005 about Teacher and Lecturer. Jakarta:

Department of National Education.

O’Malley, J.M., \& Valdez Pierce, L. (1996). Authentic assessment for English language learners: Practical approaches for teachers. New York: Addison-Wesley.

Reynolds, C., Livingston, R., \&Willson, V. (2006). Measurement and assessment in education. Boston, MA: Pearson Education, Inc.

Yarden, A., Norris, S.P., \&Phillips, L.M. (2015). Adapted Primary LiteratureThe Use of Authentic Scientific Texts in Secondary Schools. New York: Springer.

McMillan, J. H. (2013). Sage handbook of research on classroom assessment / James H. McMillan, (Ed.). India: Sage Publisher.

Marzano, R.J. (2006). Classroom assessment and Grading that Work. Alexandria, Virginia: The Association for Supervision of Curriculum Development (ASCD).

APPENDIX

Table 1

\begin{tabular}{|l|l|l|l|c|c|}
\hline \multirow{2}{*}{ COMPONENT /TOPIC } & \multirow{2}{*}{ No. } & \multicolumn{4}{|c|}{ Frequency \& Percentage Options (N = 18) } \\
\cline { 3 - 6 } & & A \% & B \% & C \% & D \% \\
\hline Teacher's understanding of CBA & 1 & $1(5,55)$ & $6(33,33)$ & $6(33,33)$ & $5(27,77)$ \\
\hline Main point of CBA & 2 & $3(16,66)$ & $4(22,22)$ & $6(33,33)$ & $5(27,77)$ \\
\hline
\end{tabular}


IJOTL TL, Vol. 4, No. 2, May 2019

p ISSN: 2502 2326; e -ISSN: 2502 8278

Https://soloclcs.org; Email: ijolt1@gmail.com

Center of Language and Cultural Studies, Surakarta, Indonesia

Suhirman, Lalu \& Rinantanti, Yulini. 2019. Competence of EFL Junior High School Teachers

In Implementing Classroom Assessment in Merauke District, Papua.

IJOTL TL (2019), 4(2): 65 80. DOI: 10.30957/ijot1 tl.v4i2.261

\begin{tabular}{|l|l|l|l|l|l|}
\hline Element assessed in CBA & 3 & $2(11,11)$ & $16(88,88)$ & - & - \\
\hline How CBA to carried out by the teacher & 4 & $3(16,66)$ & $2(11,11)$ & $7(38,88)$ & $6(33,33)$ \\
\hline Significance of CBA result for learner & 5 & $1(5,55)$ & $2(11,11)$ & $12(66,66)$ & $3(16,66)$ \\
\hline CBA functions & 6 & - & $9(50)$ & $2(11,11)$ & $7(38,88)$ \\
\hline Four categories of CBA & 7 & $7(38,88)$ & $9(50)$ & $2(11,11)$ & - \\
\hline CBA significance for remedial \& reinforcement & 8 & $2(11,11)$ & $6(33,33)$ & $9(50)$ & $1(5,55)$ \\
\hline Understanding the principles of CBA & 9 & $1(5,55)$ & $5(27,77)$ & $5(27,77)$ & $7(38,88)$ \\
\hline Nine principles of CBA & 10 & - & $1(5,55)$ & $12(66,66)$ & $5(27,77)$ \\
\hline One of CBA principle is competency & 11 & $1(5,55)$ & $1(5,55)$ & $2(11,11)$ & $14(22,22)$ \\
\hline CBA principle is continuously & 12 & $1(5,55)$ & $15(83,33)$ & $2(11,11)$ & - \\
\hline CBA significance for stakeholders & 13 & $3(16,66)$ & $1(5,55)$ & $13(72,22)$ & $1(5,55)$ \\
\hline CBA to diagnose student's competency & 14 & $4(22,22)$ & $10(55,55)$ & $3(16,66)$ & $1(5,55)$ \\
\hline CBA is useful to improve learning program & 15 & $2(11,11)$ & $1(5,55)$ & $7(38,88)$ & $8(44,44)$ \\
\hline CBA is also useful for learner's feedback & 16 & $7(38,88)$ & $3(16,66)$ & $4(22,22)$ & $4(22,22)$ \\
\hline Understanding project assessment & 17 & $2(11,11)$ & $10(55,55)$ & $1(5,55)$ & $5(27,77)$ \\
\hline
\end{tabular}

Table 2

\begin{tabular}{|l|l|l|l|l|l|}
\hline \multirow{2}{*}{ COMPONENT/TOPIC } & \multirow{2}{*}{\begin{tabular}{l} 
No. \\
\cline { 3 - 6 }
\end{tabular}} & \multicolumn{4}{c|}{ Arequency \& Percentage Options (N=18) } \\
\hline Other form of CBA (portfolio, project, product,etc. & 18 & $1(5,55)$ & $5(27,77)$ & $2(11,11)$ & $10(55,55)$ \\
\hline Understanding CBA form (no. 18) & 19 & $3(16,66)$ & $7(38,88)$ & $5(27,77))$ & $3(16,66)$ \\
\hline How often do you use CBA forms (no.18) & 20 & $8(44,44)$ & $8(44,44)$ & $2(11,11)$ & - \\
\hline Always assess in each learning activity? & 21 & $4(22,22)$ & $9(50)$ & $5(27,77)$ & - \\
\hline Conduct reflection after teaching & 22 & $4(22,22)$ & $9(50)$ & $5(27,27)$ & - \\
\hline Assess with various ways & 23 & - & - & $2(11,11)$ & $1(88,88)$ \\
\hline
\end{tabular}

Table 3

\begin{tabular}{|l|l|l|l|l|l|}
\hline \multirow{2}{*}{ COMPONENT / TOPIC } & \multirow{2}{*}{} & \multicolumn{4}{c|}{ Frequency \& Percentage Options (N = 18) } \\
\cline { 5 - 7 } & No. & \multicolumn{1}{|c|}{ A \% } & \multicolumn{1}{c|}{ B \% } & \multicolumn{1}{c|}{ C \% } & \multicolumn{1}{c|}{ D \% } \\
\hline Performance assessment & 24 & $2(11,11)$ & $4(22,22)$ & $1(5,55)$ & $11(61,66)$ \\
\hline Authentic assessment principles & 25 & $4(22,22)$ & $1(5,55)$ & $13(72,22)$ & - \\
\hline Time to conduct authentic assessment & 26 & $4(22,22)$ & $4(22,22)$ & $10(55,55)$ & - \\
\hline reference indicator for assessing student abilities & 27 & $1(5,55)$ & $8(44,44)$ & $6(33,33)$ & $3(16,66)$ \\
\hline Authentic assessment characteristics & 28 & $4(22,22)$ & $9(50)$ & $3(16,66)$ & $2(11,11)$ \\
\hline How often to conduct CBA? & 29 & $6(33,33)$ & $10(55,55)$ & $2(11,11)$ & - \\
\hline Frequency giving feedback to learners & 30 & $4(22,22)$ & $4(22,22)$ & $10(55,55)$ & - \\
\hline Principles of authentic assessment & 31 & $7(38,88)$ & $5(27,77)$ & $2(11,11)$ & $4(22,22)$ \\
\hline Frequency to conduct authentic in CBA & 32 & $9(50)$ & $6(33,33)$ & $3(16,66)$ & - \\
\hline Objective of authentic assessment & 33 & $6(33,33)$ & $6(33,33)$ & $6(33,33)$ & - \\
\hline How to conduct assessment process? & 34 & - & - & $6(33,33)$ & $12(66,66)$ \\
\hline
\end{tabular}


IJOTL TL, Vol. 4, No. 2, May 2019

p ISSN: 2502 2326; e ISSN: 2502 8278

Https://soloclcs.org; Email: ijolt1@gmail.com

Center of Language and Cultural Studies, Surakarta, Indonesia

Suhirman, Lalu \& Rinantanti, Yulini. 2019. Competence of EFL Junior High School Teachers

In Implementing Classroom Assessment in Merauke District, Papua.

IJOTL TL (2019), 4(2): 65 80. DOI: 10.30957/ijot1 tl.v4i2.261

Table 4

\begin{tabular}{|c|c|c|c|c|c|}
\hline \multirow[t]{2}{*}{ COMPONENT/ TOPIC } & \multirow[b]{2}{*}{ No. } & \multicolumn{4}{|c|}{ Frequency \& Percentage Options $(\mathrm{N}=18)$} \\
\hline & & A \% & B \% & C \% & $\mathrm{D} \%$ \\
\hline CBA conduct in various ways & 35 & $4(22,22)$ & $6(33,33)$ & $6(33,33)$ & $2(11,11)$ \\
\hline Frequency conducting CBA (no.35) & 36 & - & $7(38,88)$ & $6(33,33)$ & $5(27,77)$ \\
\hline Understanding to conduct CBA (no.35) & 37 & $1(5,55)$ & $7(38,88)$ & $8(44,44)$ & $2(11,11)$ \\
\hline Understanding portofolio & 38 & $2(11,11)$ & $13(72,22)$ & $3(16,66)$ & - \\
\hline Understanding kinds of portofolio & 39 & - & - & $3(16,66)$ & $15(83,33)$ \\
\hline Understanding term of portofolio & 40 & $12(66,66)$ & - & $3(16,66)$ & $3(16,66)$ \\
\hline Portofolio is part of authentic assessment & 41 & $12(66,66)$ & $3(16,66)$ & - & $3(16,66)$ \\
\hline Frequency conducting portofolio & 42 & $5(27,77)$ & $1(5,55)$ & $2(11,11)$ & $10(55,55)$ \\
\hline Objective of portofolio & 43 & - & $6(33,33)$ & $3(16,66)$ & $9(50)$ \\
\hline Portofolio different with test & 44 & $3(16,66)$ & $10(55,55)$ & $5(27,77)$ & - \\
\hline Portofolio focuses on cognitive, affect.,and motoric & 45 & $4(22,22)$ & $1(5,55)$ & $13(72,77)$ & - \\
\hline Test commonly focus on & 46 & $1(5,55)$ & - & $7(38,88)$ & $10(55,55)$ \\
\hline Test commonly conducted & 47 & $6(33,33)$ & $5(27,77)$ & $7(38,88$ & - \\
\hline Principles of portofolio & 48 & $6(33,33)$ & $6(33,33)$ & $5(27,77)$ & $1(5,55)$ \\
\hline
\end{tabular}

